\title{
INTEGRASI HARGA DAGING SAPI DI PASAR DOMESTIK DAN INTERNASIONAL
}

\author{
Integration of Beef Prices in the Domestic and International Market
}

\author{
Ahmad Zainuddin ${ }^{1}$, Ratna Winandi Asmarantaka ${ }^{2}$, Harianto ${ }^{2}$ \\ ${ }^{1}$ Program Studi IImu Ekonomi Pertanian, Sekolah Pascasarjana IPB \\ Jl. Kamper, Wing 5 Level 4, Kampus IPB Darmaga, Bogor \\ ${ }^{2}$ Departemen Agribisnis, Fakultas Ekonomi dan Manajemen IPB \\ Jl. Kamper, Wing 4 Level 5, Kampus IPB Darmaga, Bogor \\ e-mail : nidduniaz.ahmad@gmail.com
}

Naskah diterima: 13/04/2015 Naskah direvisi: 08/05/2015 Disetujui diterbitkan: 18/06/2015

\begin{abstract}
Abstrak
Permintaan daging sapi di Indonesia yang terus meningkat menyebabkan kesenjangan semakin melebar antara produksi dan konsumsi. Kelebihan permintaan tersebut dipenuhi oleh daging sapi impor yang menyebabkan harga daging sapi domestik mengikuti pergerakan harga daging sapi impor. Penelitian ini bertujuan untuk menganalisis integrasi pasar daging sapi Indonesia dan dunia (respon harga daging sapi domestik terhadap perubahan harga internasional/dunia). Data yang digunakan adalah data sekunder berupa data bulanan harga retail daging sapi di Indonesia dan harga daging sapi internasional (periode 2009-2013). Analisis data menggunakan model Vector Error Correction Model (VECM). Hasil penelitian menunjukkan terjadi integrasi antara harga daging sapi di pasar domestik dan dunia dalam jangka panjang dan jangka pendek. Hal ini berimplikasi terhadap stabilitas harga daging sapi Indonesia tergantung pada harga daging sapi di pasar dunia. Oleh karena itu, pemerintah melalui Kementerian Perdagangan perlu menerapkan kebijakan stabilitas harga daging sapi agar konsumen dapat menjangkau harga daging sapi yang terus meningkat serta produsen juga tidak dirugikan.
\end{abstract}

Kata kunci: Integrasi Pasar, Daging Sapi, Perubahan Harga.

\begin{abstract}
The increasing demand of beef in Indonesia has broadened the gaps between production and consumption. This excess demand is solved by importing beef which consequently makes the price of domestic beef follows the imported ones. This research aims to analyze the integration of beef market in Indonesia compared to the world market (as a response of domestic beef prices against the international/world price changes). The study used secondary data including the monthly retail price of beef in Indonesia and international beef prices during 2009-2013. Data analysis used was Vector Error Correction Model (VECM). The result shows that there is price integration between domestic beef market and the world market in the long and short run. It gives an implication to the stability of Indonesian beef price which depends heavily on the world market's price. It is necessary that the government through the Ministry of Trade implement a policy of beef price stability so that the consumers will be able to purchase beef even the price keeps increasing and the producers will not lose the market.
\end{abstract}

Keywords: Market Integration, Beef, Price Change.

JEL Classification: Q13, Q22, Q11 


\section{PENDAHULUAN}

Daging sapi merupakan salah satu komoditas pertanian penting dan strategis di Indonesia. Terdapat beberapa alasan yang membuat daging sapi memiliki peran penting dan strategis yaitu (1) pengembangan komoditas daging sapi sebagai bagian dari subsektor peternakan berpotensi menjadi sumber pertumbuhan baru bagi peningkatan PDB sektor pertanian (sumbangan PDB peternakan dan hasil-hasilnya berkisar $12 \%$ terhadap PDB sektor pertanian); (2) terdapat 5,74 juta rumah tangga yang terlibat dalam usaha peternakan sapi potong (Ditjen Peternakan dan Kesehatan Hewan, 2013); (3) sentra produksi daging sapi tersebar di banyak daerah, sedangkan sentra konsumsi terpusat di perkotaan sehingga mampu menggerakkan perekonomian regional; (4) pengembangan produksi komoditas daging sapi mendukung upaya peningkatan ketahanan pangan dan ketersediaan pangan (Ilham, 2006).

Selama dasawarsa terakhirkonsumsi daging sapi cenderung mengalami peningkatan dimana peningkatan konsumsi daging sapi lebih tinggi dari peningkatan produksi daging sapi. Hal ini sejalan dengan meningkatnya jumlah penduduk Indonesia sehingga konsumsi daging sapi juga meningkat. Sedangkan pertumbuhan populasi sapi nasional yang mendukung produksi daging sapi cenderung mengalami peningkatan secara lamban. Berdasarkan data dari Kementerian Pertanian selama periode 1999-2012 produksi daging sapi dalam negeri berfluktuasi, meskipun menunjukkan adanya tren kenaikan. Sedangkan konsumsi dalam negeri cenderung mengalami kenaikan setiap tahunnya dengan laju peningkatan konsumsi daging sapi yang mencapai $4,66 \%$, dibandingkan dengan laju peningkatan produksi sapi potong sebesar $3,2 \%$, sehingga dalam jangka panjang akan menyebabkan terjadinya kelebihan permintaan. Kelebihan permintaan tersebut dipenuhi oleh daging sapi yang berasal dari impor (Harmini et al, 2011).

Selama ini kebutuhan daging sapi Indonesia dipenuhi dari tiga sumber, yaitu sapi lokal, sapi impor dan daging sapi impor. Untuk menutupi kekurangan penawaran daging sapi dalam negeri dilakukan impor dari berbagai negera, terutama Australia dan Selandia Baru (Kusriatmi, 2014; Ilham, 2009; Maraya, 2013; Istiqomah, 2014). Selama sepuluh tahun terakhir laju perkembangan impor daging sapi cenderung mengalami peningkatan yang signifikan yaitu pada tahun 2011 jumlah impor daging sapi sebesar $35,59 \%$ dan jumlah impor daging sapi tersebut meningkat pada tahun 2012 mencapai 42,08\%. Proporsi Perkembangan impor daging sapi mengalami peningkatan seiring meningkatnya konsumsi daging sapi dalam negeri (Ditjen Peternakan dan Kesehatan Hewan, 2013).

Menurut Tseuoa (2011), kebijakan izin impor sapi bakalan dan daging sapi yang dikeluarkan pemerintah tahun 1980an semula untuk menyediakan daging murah, sehingga konsumsi daging masyarakat meningkat. Namun, pada tahun 2012 proporsi daging sapi impor telah mencapai 
369693 ton dari kebutuhan daging sapi nasional, sehingga mengkhawatirkan kedaulatan dan ketahanan pangan. Mengatasi perihal tersebut pemerintah mencanangkan Program Swasembada Daging Sapi (PSDS) 2014. Program Swasembada Daging Sapi pada tahun 2014 sebenarnya merupakan ketiga kalinya yang dicanangkan pemerintah. Melalui kebijakan ini ketergantungan atas impor sapi dan impor daging sapi diperkecil dengan meningkatkan potensi sapi dalam negeri. Sasarannya adalah agar impor sapi dan daging sapi hanya mencapai $10 \%$ dari total kebutuhan masyarakat.

Adanya liberalisasi perdagangan antar negara menyebabkan pasar Indonesia menjadi sasaran produk impor, salah satunya adalah daging sapi impor dan sapi impor. Perdagangan bebas antar negara mengisyaratkan penurunan tarif impor produk ternak 10 menjadi $5 \%$ dan menurunkan tarif impor sapi bibit dan sapi bakalan menjadi $0 \%$ (Ilham, 2009). Liberalisasi pasar daging sapi, dimana bea masuk daging sapi dari luar negeri menjadi lebih rendah dari sebelumnya berimplikasi terhadap harga daging sapi impor menjadi jauh lebih murah dan harga daging sapi lokal yang mengikuti pergerakan harga daging sapi impor juga menjadi lebih murah dari sebelumnya. Hal ini menyebabkan fluktuasi harga daging sapi di pasar domestik sepenuhnya mengikuti mekanisme pasar. Harga impor daging sapi Indonesia juga berfluktuasi dari tahun ke tahun, namun perubahan yang terjadi pada pasar dunia tidak berarti juga perubahan dengan tingkat yang sama pada harga impor daging sapi Indonesia. Perubahan harga daging sapi dunia (impor) akan mempengaruhi terhadap konsumsi daging sapi masyarakat Indonesia yang cenderung bersifat elastis terhadap harga (Sutawi, 2007).

Fluktuasi harga daging sapi yang terjadi di pasar dunia segera direspon ke pasar domestik. Harga daging sapi dunia dapat mempengaruhi harga daging sapi domestik yang ditunjukkan apabila harga dunia mengalami fluktuasi maka harga daging sapi domestik juga berfluktuasi. Fluktuasi harga daging sapi domestik memiliki kecenderungan yang sama dengan harga dunia. Meskipun fluktuasi harga daging sapi domestik mengikuti fluktuasi harga daging sapidunia, integrasi pasar daging sapi dunia dengan pasar daging sapi domestik belum tentu terjadi. Adanya hubungan kedua pasar daging sapi yang saling terintegrasi merupakan salah satu indikator yang menunjukkan terjadinya efisiensi pemasaran daging sapi di Indonesia. Hal ini karena integrasi pasar merupakan salah satu cara mengukur efisiensi pemasaran terutama efisiensi harga.

Integrasi atau keterpaduan pasar merupakan salah satu indikator dari efisiensi pemasaran, khususnya efisiensi harga. Asmarantaka (2009) menyatakan bahwa integrasi pasar merupakan suatu ukuran yang menunjukkan seberapa besar perubahan harga yang terjadi di pasar acuan (pasar pada tingkat yang lebih tinggi seperti pedagang eceran) akan menyebabkan terjadinya perubahan pada pasar pengikutnya (misalnya pasar di tingkat petani). Dengan demikian analisis integrasi pasar sangat erat kaitannya dengan analisis 
struktur pasar. Dua tingkatan pasar dikatakan terpadu atau terintegrasi jika perubahan harga pada salah satu tingkat pasar disalurkan atau ditransfer ke pasar lain. Yustiningsih (2012) menyebutkan bahwa dalam struktur pasar persaingan sempurna, perubahan harga pada pasar acuan akan ditransfer secara sempurna $(100 \%)$ ke pasar pengikut, yakni di tingkat petani. Integrasi pasar akan tercapai jika terdapat informasi pasar yang memadai dan disalurkan dengan cepat ke pasar lain sehingga partisipan yang terlibat di kedua tingkat pasar (pasar acuan dan pasar pengikut) memiliki informasi yang sama.

Integrasi pasar dapat dibedakan atas dua jenis yaitu integrasi pasar spasial dan vertikal. Integrasi pasar spasial merupakan keterkaitan hubungan antara pasar regional dan pasar regional lainnya. Menurut Tomek \& Robinson (1990), hubungan suatu harga dari pasar yang terpisah secara geografis untuk komoditi yang sama dapat dianalisa dengan konsep integrasi pasar spasial. Dua pasar dikatakan terintegrasi apabila perubahan harga pada satu pasar akan mempengaruhi harga pasar lainnya dengan arah yang sama dan tingkat yang sama pula. Selain itu jika terjadi perdagangan antara dua wilayah, kemudian harga di wilayah yang mengimpor komoditi sama dengan harga di wilayah yang mengekspor komoditi ditambah dengan biaya transportasi yang timbul karena perpindahan diantara keduanya maka dapat dikatakan keduanya terjadi integrasi spasial (Ravallion, 1986). Sedangkan integrasi vertikal merupakan integrasi yang dipahami terjadi dalam suatu industri (sistem agribisnis) merupakan keterkaitan lembaga pemasaran dengan lembaga pemasaran lainnya dalam satu rantai pemasaran (misal dari lembaga di tingkat petani dengan lembaga di pabrik atau di tingkat konsumen) (Asmarantaka, 2012).

Analisis Kointegrasi merupakan prosedur alternatif untuk mengevaluasi hubungan pasar spasial dengan menganalisis tren stokastik dalam data harga ke dalam model. Ini dikembangkan dan diterapkan dalam penelitian sebelumnya oleh Engle \& Granger (1987). Engle \& Granger telah menemukan bahwa banyak data yang berupa data time series tidak dalam keadaan stasioner, berarti varians konstan dari waktu ke waktu, tetapi tidak stasioner (Engle \& Granger, 1987). Analisis Kointegrasi memastikan bahwa penyimpangan dari kondisi keseimbangan antara dua variabel ekonomi yang secara individual non-stasioner dalam jangka pendek harus stasioner dalam jangka panjang (Goodwin \& Schroeder, 1991). Oleh karena itu, jika harga pasar terkointegrasi, dengan demikian, pasar bersangkutan terintegrasi (Negassa et al, 2003). Dengan kata lain, integrasi pasar merupakan indikasi saling ketergantungan antara dua pasar atau lebih.

Penelitian mengenai integrasi pasar daging sapi sudah pernah dilakukan di beberapa negara seperti penelitian Diakosavvas (1995) dengan menggunakan analisis kointegrasi didasarkan pada pendekatan regresi linear. Tujuan penelitian adalah untuk menguji integrasi pasar antara harga daging sapi Australia dan Amerika Serikat (AS) di tingkat petani. Dengan 
menggunakan data time series bulanan dari 1972-1993. Hasil penelitian menunjukkan kointegrasi ditemukan antara harga daging sapi Australia dan AS. Analisis konvergensi menunjukkan tingkat konvergensi antara berbagai pasangan harga belum meningkat dari waktu ke waktu. Hasilnya menunjukkan bahwa harga Australia tidak dapat diadopsi sebagai harga dunia dalam analisis empiris, sehingga harga daging sapi di Amerika Serikat tidak merespon terhadap perubahan harga daging sapi di Australia yang mewakili harga dunia.

Fossati et al (2012) dalam penelitiannya yang berjudul "International Price Transmission and Market Integration: The Case of a Small Open Economy" melakukan analisis mengenai integrasi pasar regional dan internasional untuk komoditas pertanian seperti sorgum, jagung dan daging sapi. Penelitian ini menggunakan model multivariat cointegration. Penelitian ini dilakukan di Uruguay. Hasil penelitian menyebutkan bahwa untuk komoditas sorgum dan jagung terdapat integrasi pasar yang kuat baik antar pasar regional maupun pasar internasional dalam jangka panjang dan jangka pendek, sedangkan hasil yang berbeda ditemukan pada komoditas daging sapi, dimana pada komoditas daging sapi ditemukan integrasi pasar antara pasar regional dan internasional dalam jangka panjang yang ditunjukkan dengan adanya kointegrasi, sedangkan dalam jangka pendek, tidak terjadi integrasi pasar antara pasar daging sapi di Uruguay dengan pasar internasional (Australia dan Selandia Baru), namun terjadi integrasi pasar antar pasar regional.
Harga daging sapi di Indonesia penting untuk dikaji karena daging sapi merupakan salah satu bahan pangan pokok selain komoditas beras yang berpengaruh signifikan terhadap inflasi. Di samping itu, harga daging sapi juga mempengaruhi keputusan-keputusan produksi. Fluktuasi harga daging sapi akan memunculkan risiko seperti berhentinya produksi akibat harga jual yang terlalu rendah. Ketika pasar tidak terintegrasi, maka kenaikan harga akan menurunkan daya beli masyarakat dan penurunan harga akan menyebabkan kerugian bagi produsen ternak sapi, sehingga kebijakan pemerintah diperlukan saat pasar belum berjalan efisien.

Berdasarkan latar belakang di atas, tulisan ini akan meneliti respon perubahan harga daging sapi domestik terhadap perkembangan harga daging sapi dunia yaitu dengan menggunakan analisis integrasi pasar. Oleh karena itu, menjadi penting untuk dilakukan penelitian mengenai respon perubahan harga daging sapi domestik terhadap perkembangan harga internasional. Penelitian ini bertujuan untuk menganalisis integrasi pasar daging sapi domestik dengan pasar daging sapi dunia (hubungan harga daging sapi domestik dengan harga internasional).

\section{METODE}

Pengujian hipotesis mengenai analisis integrasi pasar spasial antara pasar daging sapi domestik dengan pasar daging sapi dunia digunakan model VAR (Vector Autoregression)/ VECM (Vector Error Correction Model). 
Model VAR (Vector Autoregressive)/ VECM (Vector Error Correction Model) digunakan untuk menganalisis ada tidaknya kesaling-tergantungan harga daging sapi secara spasial antar pasar. Analisis integrasi pasar spasial ini memasukkan harga daging sapi internasional, dengan pertimbangan bahwa Indonesia merupakan negara importir daging sapi dalam jumlah besar di dunia, sehingga menurut harga daging sapi Indonesia akan dipengaruhi oleh harga daging sapi di pasar internasional.

Model VAR/VECM adalah suatu sistem persamaan yang memperlihatkan setiap variabel sebagai fungsi linier dari konstanta dan nilai lag (lampau) dari variabel itu sendiri serta nilai lag dari variabel lain yang ada di dalam sistem. Sehingga, variabel penjelas dalam Model VAR/VECM meliputi nilai lag dari seluruh variabel tak bebas dalam sistem. Di dalam model VAR/ VECM diasumsikan semua variabel tak bebas bersifat stasioner dan semua galat bersifat whitenoise, yakni memiliki rataan nol, ragam konstan dan saling bebas. Variabel tak bebas yang tidak stasioner akan menghasilkan regresi semu (spurious regression). Variabel tak bebas yang tidak stasioner seringkali menunjukkan hubungan ketidakseimbangan dalam jangka pendek, namun ada kecenderungan terdapat hubungan keseimbangan dalam jangka panjang. Model yang digunakan untuk mengatasi ketidakstasioner data adalah model VEC (Vector Error Correction), dimana model ini akan mengkoreksi secara bertahap adanya ketidakseimbangan tersebut deviasi melalui penyesuaian parsial jangka pendek (Enders, 1995; dan Gujarati, 2004). Adapun model VAR dari integrasi pasar daging sapi domestik dengan pasar daging sapi dunia adalah sebagai berikut:

$$
\begin{aligned}
& \operatorname{Pdom}_{\mathrm{t}}=\alpha_{1}+\delta_{1} \mathrm{t}+\phi_{11} \text { Pdom }_{\mathrm{t}-1}+\ldots+ \\
& \phi_{1 \mathrm{p}} \mathrm{Pdom}_{\mathrm{t}-\mathrm{p}}+\beta_{11} \mathrm{Pdun}_{\mathrm{t}-1}+\ldots+ \\
& \beta_{1 \mathrm{q}} \text { Pdun }_{\mathrm{t}-\mathrm{q}}+\varepsilon_{\mathrm{t}} \\
& \text { Pdun }_{\mathrm{t}}=\alpha_{2}+\delta_{2} \mathrm{t}+\phi_{21} \operatorname{Pdun}_{\mathrm{t}-1}+\ldots+ \\
& \phi_{2 p} \text { Pdun }_{t-p}+\beta_{21} P \text { dom }_{t-1}+\ldots+ \\
& \beta_{1 q} P d_{0 m}+\varepsilon_{t}
\end{aligned}
$$

dimana Pdom $\mathrm{t}_{\mathrm{t}}$ adalah vektor $n \times 1$ dari harga daging sapi di pasar domestik pada orde satu, umumnya dinotasikan I(1); Pdun ${ }_{t}$ merupakan harga daging sapi dunia dan $\varepsilon$ t adalah $n \times 1$ vektor inovasi (Rosadi, 2012). Pada penelitian ini $n$ yang diteliti berjumlah 2 variabel harga (harga daging sapi domestik dan harga daging sapi dunia). Apabila variabel - variabel tersebut ditransformasikan ke dalam bentuk vektor terlihat pada formulasi di bawah ini:

$\left[\begin{array}{c}\operatorname{Pdom}_{\mathrm{t}} \\ \text { Pdun }_{\mathrm{t}}\end{array}\right]=\left[\begin{array}{l}\beta_{1} \\ \beta_{2}\end{array}\right]+\left[\begin{array}{ll}\beta_{11} & \beta_{12} \\ \beta_{21} & \beta_{22}\end{array}\right]\left[\begin{array}{l}\operatorname{Pdom}_{\mathrm{t}-1} \\ \operatorname{Pdun}_{\mathrm{t}-1}\end{array}\right]+\left[\begin{array}{l}\varepsilon_{1 \mathrm{t}} \\ \varepsilon_{2 \mathrm{t}}\end{array}\right]$

dimana:

Pdom : harga daging sapi domestik $(\mathrm{Rp} / \mathrm{kg})$

Pdun : harga daging sapi dunia $(\mathrm{Rp} /$ $\mathrm{kg}$ )

$\alpha_{i} \quad$ : parameter yang akan diestimasi

Adapun spesifikasi model VECM integrasi pasar daging sapi domestik dengan pasar internasional adalah sebagai berikut : 


$$
\begin{aligned}
& \Delta \mathrm{Pdom}_{\mathrm{t}}=\varphi_{1}+\delta_{1} \mathrm{t}+\lambda_{1} \mathrm{e}_{\mathrm{t}-1}+\mathrm{\gamma}_{11} \Delta \mathrm{Pdom}_{\mathrm{t}-1} \\
& +\ldots+Y_{1 p} \Delta \text { Pdom }_{\mathrm{t}-\mathrm{p}} \\
& +\omega_{11} \Delta \text { Pdun }_{\mathrm{t}-1}+\ldots+\omega_{1 q} \Delta \text { Pdun }_{\mathrm{t}-\mathrm{a}} \\
& +\varepsilon_{1 \mathrm{t}} \ldots \ldots \ldots \ldots \ldots \\
& \Delta \text { Pdun }_{\mathrm{t}}=\varphi_{2}+\delta_{2} \mathrm{t}+\lambda_{2} \mathrm{e}_{\mathrm{t}-1}+\mathrm{\gamma}_{21} \Delta \text { Pdun }_{\mathrm{t}-1} \\
& +\cdots+\mathrm{Y}_{2 \mathrm{p}} \Delta \text { Pdun }_{\mathrm{t}-\mathrm{p}} \\
& +\omega_{21} \Delta \mathrm{Pdom} \mathrm{m}_{\mathrm{t}-1}+\ldots+ \\
& \omega_{2 q} \Delta \text { Pdom }_{\mathrm{t}-\mathrm{q}}+\varepsilon_{2 \mathrm{t}}
\end{aligned}
$$

Dimana:

Pdom $_{t} \quad$ : vektor yang berisi variabel yang dianalisis dalam penelitian (harga daging sapi domestik (Rp/kg)

Pdun $_{\mathrm{t}} \quad$ : harga daging sapi dunia (Rp/ $\mathrm{kg}$ )

$\varphi_{\mathrm{x}} \quad:$ vektor intercept

$\mathrm{V}_{2 \mathrm{p} ;} \omega_{2 \mathrm{q}}$ : vektor koefisien regresi

$\mathrm{t} \quad$ : time tren

$Y_{2 p} \quad: \operatorname{ax} \beta^{\prime}$ dimana b' mengandung persamaan kointegrasi jangka panjang

$\mathrm{Y}_{\mathrm{t}-1} ; \mathrm{X}_{\mathrm{t}-1} \quad$ : variabel in-level

$\lambda_{\mathrm{x}} \quad$ : matriks koefisien regresi yang menunjukkan adanya integrasi jangka pendek

$\varepsilon_{t} \quad:$ error term

Tahapan pengolahan data dengan menggunakan model VAR/VECM adalah:

a) Uji Stationeritas atau Unit Root Test

Langkah pertama yang harus dilakukan dalam estimasi model ekonomi dengan data time series adalah dengan menguji stasioneritas pada data atau disebut juga stationary stochastic process. Kestasioneran diperlukan untuk menghindari adanya spurious regression (regresi palsu). Suatu persamaan dikatakan stasioner apabila memiliki mean, variance, dan covariance yang konstan pada setiap lag dan tidak mengandung unit root. Uji stasioneritas data ini dapat dilakukan dengan menggunakan Augmented Dickey-Fuller (ADF) pada derajat yang sama (level atau different) hingga diperoleh suatu data yang stasioner, yaitu data yang variansnya tidak terlalu besar dan mempunyai kecenderungan untuk mendekati nilai rata-ratanya (Enders, 1995).

Pengujian akar-akar unit dilakukan guna menganalisis apakah suatu variabel stationer atau tidak stationer. Uji stationeritas data tersebut merupakan tahap yang apaling penting dalam menganalisis data time series untuk mengetahui ada tidaknya akar unit yang terdapat pada variabel, sehingga hubungan antar variabel menjadi valid. Stationeritas data deret waktu (time series) merupakan syarat penting dalam menganalisis model ekonometrika agar terhindar dari regresi lancung (spurious regression).

Widarjono (2012) menjelaskan bahwa fungsi uji ADF adalah untuk melihat ada tidaknya tren di dalam pergerakan data yang akan diuji. Uji ADF terdiri dari perhitungan regresi yang dirumuskan sebagai berikut.

$$
\begin{aligned}
& \left.\Delta Y_{t}=\gamma Y_{t-1}+\beta_{i} \sum_{t=1}^{p} \Delta Y_{t-i}+\varepsilon_{t} \ldots \ldots \ldots \ldots \ldots . .6\right) \\
& \Delta Y_{t}=\alpha_{0}+\gamma Y_{t-1}+\beta_{i} \sum_{t=1}^{p} \Delta Y_{t-i}+\varepsilon_{t} \ldots \ldots \ldots(7) \\
& \Delta Y_{t}=\alpha_{0}+\alpha_{1} t+\gamma Y_{t-1}+\beta_{i} \sum_{t=1}^{\rho} \Delta Y_{t-i}+\varepsilon_{t} \ldots(8)
\end{aligned}
$$


dimana :

$\begin{array}{ll}\Delta \mathrm{Y}_{\mathrm{t}} & : \text { Selisih variabel }\left(\mathrm{Y}_{\mathrm{t}}-\mathrm{Y}_{\mathrm{t}-1}\right) \\ \mathrm{Y} & :(\rho-1) \\ \alpha_{0}, \alpha_{1}, \mathrm{Y}, \beta_{\mathrm{i}} & : \text { Koefisien } \\ \mathrm{t} & : \text { Tren waktu } \\ \mathrm{Y} & : \text { Variabel yang diuji } \\ & \text { stasioneritasnya (harga } \\ & \text { daging sapi domestik (Rp/ } \\ & \mathrm{kg}), \text { harga daging sapi } \\ & \text { dunia (Rp/kg)) } \\ & : \text { Panjang lag yang } \\ & \text { digunakan dalam model } \\ \mathrm{P} & : \text { Error persamaan }\end{array}$

Perbedaan persamaan 1 (satu) dengan dua regresi lainnya adalah memasukkan konstanta dan variabel tren waktu. Persamaan 1 (satu) digunakan pada data observasi yang diasumsikan hanya memiliki intersep, tidak memiliki konstanta dan tren. Persamaan 2 digunakan dengan asumsi data observasi terdapat konstanta dan intersep. Persamaan 3 digunakan apabila data observasi diasumsikan memiliki komponen konstanta, intersep, dan tren. Hipotesis dalam uji ini adalah $\mathrm{H}_{0}$ jika $\mathrm{Y}=0$ berarti data time series mengandung unit root yang bersifat tidak stasioner dan $\mathrm{H}_{1}$ jika $\mathrm{Y}<1$ berarti data bersifat stasioner.

Penggunaan aplikasi program Eviews 6 mengkategorikan data tersebut stasioner atau tidak dengan membandingkan nilai Mackinnon critical dengan nilai mutlak ADFstatistiknya. Jika dalam uji stasioneritas ini menunjukkan nilai ADFstatistik yang lebih besar daripada Mackinnon critical value, maka dapat diketahui bahwa data tersebut stasioner karena tidak mengandung unit root. Sebaliknya, jika nilai ADFstatistik lebih kecil daripada Mackinnon critical value, maka dapat disimpulkan bahwa data tersebut tidak stasioner pada derajat level. Dengan demikian, differencing data untuk memperoleh data yang stasioner pada derajat yang sama di first different I (1) harus dilakukan, yaitu dengan mengurangi data tersebut dengan data periode sebelumnya (Aija et al. 2011). Jika data sudah stasioner sejak awal maka model VAR in level dapat langsung dilakukan. Jika data belum stasioner, maka harus melalui proses differencing, kemungkinan model yang digunakan adalah model VAR in difference (VARD) dan Vector Error Correction Model (VECM).

\section{b) Penentuan Lag Optimum}

Selanjutnya, untuk mengetahui jumlah lag optimal yang digunakan dalam uji stasioneritas, menurut Enders (1995) berikut adalah kriteria yang digunakan:

Akaike Information Criterion (AIC) :

$T \log |\Sigma|+2 \mathrm{~N}$

Schwarz Bayesian Criterion (SBC) :

$\mathrm{T} \log |\Sigma|+N \log (\mathrm{T})$

Dimana :

$\mathrm{T} \quad$ : Jumlah observasi

$|\Sigma| \quad$ : Determinan dari matriks varians/kovarians dari sisaan

$\mathrm{N} \quad$ : Jumlah parameter yang diestimasi

Dalam penentuan lag optimal dengan menggunakan kriteria informasi tersebut, kriteria yang dipilih adalah 
kriteria yang mempunyai jumlah dari AIC dan SBC yang paling kecil di antara berbagai lag yang dianjurkan. Bila semakin kecil nilai kriteria tersebut, maka nilai harapan yang dihasilkan oleh sebuah model akan semakin mendekati kenyataan. Sedangkan jika beberapa kriteria tersebut digunakan maka ada kriteria tambahan yaitu adjusted $\mathrm{R}^{2}$ sistem VAR. Panjang kelambanan optimal terjadijika nilai adjusted $\mathrm{R}^{2}$ adalah paling tinggi. Penentuan selang atau lag optimal merupakan tahapan yang penting dalam pendekatan VAR/VECM. Hal ini dikarenakan selang dari variabel endogen dalam sistem persamaan VAR/ VECM akan digunakan sebagai variabel eksogen. Penjangnya selang atau lag dari variabel yang optimal diperlukan untuk menangkap pengaruh variabelvariabel lainnya (Widarjono, 2012).

c) Uji Kointegrasi (Johansen

Cointegration Test)

Uji kointegrasi bertujuan untuk menentukan apakah variabel-variabel yang tidak stationer terkointegrasi atau tidak. Konsep kointegrasi yang dikemukakan oleh Engle Granger sebagai kombinasi linear dari dua atau lebih variabel yang tidak stationer dan menghasilkan variabel yang stationer. Kombinasi linear ini dikenal dengan istilah persamaan kointegrasi dan dapat diinterpretasikan sebagai hubungan keseimbangan jangka panjang di antara variabel (Firdaus, 2011). Pengujian kointegrasi dalam penelitian ini menggunakan pendekatan uji Johansen. Uji Johansen dilakukan dengan membandingkan antara nilai trace statistic dengan nilai critical value dan maximum eigenvalue dengan critical value pada taraf nyata $5 \%$. Jika trace statistic atau maximum eigenvalue lebih besar dari critical value maka mengindikasikan bahwa dalam sistem persamaan terdapat hubungan jangka panjang atau kointegrasi. Uji yang dilakukan adalah trace test yaitu mengukur jumlah vektor kointegrasi dalam data dengan menggunakan pengujian pangkat matriks kointegrasi yang dinyatakan sebagai berikut (Enders 1995) :

$$
\begin{aligned}
& \lambda_{\text {trace }(r)}=-T \sum_{t=r+1}^{n} \ln \left(1-\lambda_{t}\right) \\
& \lambda_{\max (r, r+1)}=-T \ln \left(1-\lambda_{r+1}\right) \ldots
\end{aligned}
$$

dimana:

$\lambda_{\mathrm{t}} \quad$ : Nilai dugaan akar karakteristik (eigenvalues) yang didapatkan dari estimasi matriks $\pi$

T : Jumlah observasi

$r \quad$ : Pangkat yang mengindikasikan jumlah vektor kointegrasi

Pada uji $\lambda$ trace, $\mathrm{H}_{0}$ adalah jumlah vektor kointegrasi yang hilang $\leq$ rsebagai alternatif umum. Jika $\lambda$ trace $<\lambda$ tabel maka terima $\mathrm{H}_{0}$ yang artinya kointegrasi terjadi pada rank r. Sementara pada uji $\lambda \max , \mathrm{H}_{0}$ yaitu jumlah vektor kointegrasi $=r$ adalah alternatif dari vektor kointegrasi $r+1$ (Enders, 1995). Dalam penggunaan Eviews 6, pengambilan keputusan dilakukan dengan melihat nilai trace statistic dan critical value. Jika trace statistic > critical value, persamaan tersebut terkointegrasi. Dengan demikian $\mathrm{H}_{0}=$ non-kointegrasi dengan hipotesis alternatifnya $\mathrm{H}_{1}=$ kointegrasi. Jika trace statistic > critical 
value, maka tolak $\mathrm{H}_{0}$ atau terima $\mathrm{H}_{1}$ yang artinya terjadi kointegrasi. Jika tidak terdapat kointegrasi antar variabel maka digunakan model VARD (VAR in difference), sedangkan jika dalam data yang diduga di model VAR terdapat kointegrasi maka model VAR yang digunakan adalah model VECM (Vector Error Correction Model) (Firdaus, 2011).

d) Uji Kausalitas Granger

Uji kausalitas Granger dilakukan untuk melihat hubungan kausalitas di antara variabel-variabel yang ada dalam model. Pengujian hubungan sebab akibat, dalam pengertian Granger (1969), dengan menggunakan F-test untuk menguji apakah lag informasi dalam variabel $Y$ memberikan informasi statistik yang signifikan tentang variabel $X$ dalam menjelaskan perubahan $X$. Jika tidak, maka $Y$ tidak ada hubungan sebab akibat Granger dengan $X$ (Firdaus, 2011). Dalam penelitian ini, uji kausalitas digunakan untuk melihat hubungan antar pasar daging sapi di domestik dan dunia. Apabila pengujian dengan menggunakan metode Granger test menunjukkan bahwa hubungan kausalitas terjadi dua arah (harga daging sapi domestik mempengaruhi harga daging sapi dunia, dan sebaliknya).

\section{e) Estimasi Model VAR/VECM}

Vector Error Correction Model (VECM) merupakan model VAR yang teretriksi yang digunakan untuk variabel yang tidak stationer tetapi memiliki potensi untuk terkointegrasi. Setelah pengujian kointegrasi pada model yang digunakan, maka dianjurkan untuk memasukkan persamaan kointegrasi ke dalam model yang digunakan. Pada data time series kebanyakan memiliki tingkat stationeritas pada perbedaan pertama (first difference) atau I(1) (Firdaus, 2011).

VECM merupakan bentuk VAR yang teretriksi. Retriksi tambahan ini harus diberikan karena keberadaan bentuk data yang tidak stationer pada level, tetapi terkointegrasi. Oleh karena itu, VECM sering disebut sebagai VAR bagi series nonstationer yang memiliki hubungan kointegrasi, sehingga dalam VECM terdapat speed of adjustment dari jangka pendek ke jangka panjang yang ditunjukkan oleh adanya nilai Error Correction Model. Model VAR dapat disusun setelah variabel-variabel dilihat kestasionerannya, kointegrasi, kelambanan, dan kecocokan variabel untuk dimasukkan dalam model. Berdasarkan penjelasan dari model VAR yang dilakukan oleh Widarjono (2012) dan Enders (1995), dapat diasumsikan model VAR kelambanan satu.

Jika terdapat kointegrasi pada data yang dicek kestasionerannya maka model yang digunakan adalah model VECM (Vector Error Correction Model) lag $\mathrm{p}$ rank $\mathrm{r}$. VECM merupakan bentuk VAR yang teretriksi. Retriksi tambahan ini harus diberikan karena keberadaan bentuk data yang tidak stationer pada level, tetapi terkointegrasi. VECM kemudian memanfaatkan informasi retriksi kointegrasi tersebut ke dalam spesifikasinya. Oleh karena itu, VECM sering disebut sebagai desain VAR bagi series nonstationer yang memiliki hubungan kointegrasi. Adapun spesifikasi model VECM integrasi pasar 
daging sapi domestik dengan pasar internasional adalah sebagai berikut :

$$
\begin{aligned}
& \Delta \text { Pdom }_{\mathrm{t}}=\varphi_{1}+\delta_{1} \mathrm{t}+\lambda_{1} \mathrm{e}_{\mathrm{t}-1}+\gamma_{11} \Delta \mathrm{Pdom}_{\mathrm{t}-1} \\
& +\ldots+Y_{1 p} \Delta \text { Pdom }_{t-p} \\
& +\omega_{11} \Delta \text { Pdun }_{\mathrm{t}-1}+\ldots+\omega_{1 q} \Delta \text { Pdun }_{\mathrm{t}-\mathrm{q}} \\
& +\varepsilon_{11} \\
& \text { dan } \\
& \Delta \text { Pdun }_{\mathrm{t}}=\varphi_{2}+\delta_{2} \mathrm{t}+\lambda_{2} \mathrm{e}_{\mathrm{t}-1}+\mathrm{\gamma}_{21} \Delta \mathrm{Pdun}_{\mathrm{t}-1} \\
& +\ldots+\mathrm{V}_{2 \mathrm{p}} \Delta \text { Pdun }_{\mathrm{t}-\mathrm{p}} \\
& +\omega_{21} \Delta \mathrm{Pdom} \mathrm{t}-1+\ldots+ \\
& \omega_{2 q} \Delta \text { Pdom }_{\mathrm{t}-\mathrm{q}}+\varepsilon_{2 t}
\end{aligned}
$$

Dimana:

Pdom $_{t}$ : vektor yang berisi variabel yang dianalisis dalam penelitian (harga daging sapi domestik (Rp/kg)

Pdun $_{t} \quad$ : harga daging sapi dunia $(\mathrm{Rp} /$ $\mathrm{kg}$ )

$\varphi_{\mathrm{x}} \quad$ : vektor intercept

$\mathrm{V}_{2 p ;} \omega_{2 q}:$ vektor koefisien regresi

$\mathrm{t} \quad$ : time trend

$\mathrm{V}_{2 \mathrm{p}} \quad$ : $\alpha \times \beta^{\prime}$ dimana b' mengandung persamaan kointegrasi jangka panjang

$\mathrm{Y}_{\mathrm{t}-1} ; \mathrm{X}_{\mathrm{t}-1}:$ variabel in-level

$\lambda_{x} \quad$ : matriks koefisien regresi yang menunjukkan adanya integrasi jangka pendek

$\varepsilon_{\mathrm{t}} \quad:$ error term

Software yang digunakan dalam penelitian ini yaitu Microsoft Excel untuk membuat tabulasi data dan Eviews 6 untuk mengolah data model VAR/VECM.

Data yang digunakan dalam penelitian ini adalah data sekunder. Data yang digunakan untuk menganalisis mengenai integrasi pasar daging sapi domestik dan pasar dunia berupa data sekunder dalam bentuk data deret waktu (time series) bulanan dengan periode waktu 60 series yaitu dari bulan Januari tahun 2009 hingga bulan Desember tahun 2013. Jenis data bulanan yang dikumpulkan berupa nilai nominal harga daging sapi domestik, harga nominal daging sapi dunia, dan data nominal nilai tukar rupiah terhadap dollar amerika. Data tersebut diperoleh dari Badan Pusat Statistik dan Kementerian Perdagangan Republik Indonesia. Penggunaan harga daging sapi domestik bertujuan untuk mengetahui kondisi pasar daging sapi domestik, sedangkan harga daging sapi dunia merupakan harga daging sapi impor yang telah dikonversi ke dalam satuan mata uang rupiah. Harga daging sapi dunia diketahui guna melihat kondisi pasar daging sapi dunia sehingga dengan menggunakan kedua data harga tersebut dapat diketahui hubungan antara pasar domestik dengan pasar dunia.

\section{HASIL DAN PEMBAHASAN}

Penelitian ini menganalisis mengenai integrasi pasar daging sapi antara pasar daging sapi domestik dengan pasar daging sapi dunia. Secara normatif, harga dunia akan berpengaruh positif terhadap harga daging sapi domestik, karena jika harga daging sapi dunia atau daging sapi impor meningkat maka harga daging sapi domestik juga meningkat, namun sebaliknya harga daging sapi domestik tidak dapat mempengaruhi harga daging sapi dunia karena sifat transmisi yang hanya searah karena 
Indonesia merupakan negara kecil (net importir) dengan proporsi impor Indonesia hanya sebesar $0.91 \%$ dari jumlah daging sapi dunia (FAO, 2014). Hal ini menyebabkan harga daging sapi domestik tidak dapat mempengaruhi harga dunia. Adapun pergerakan harga daging sapi domestik dan harga daging sapi dunia dapat dilihat pada Gambar 1 sebagai berikut:

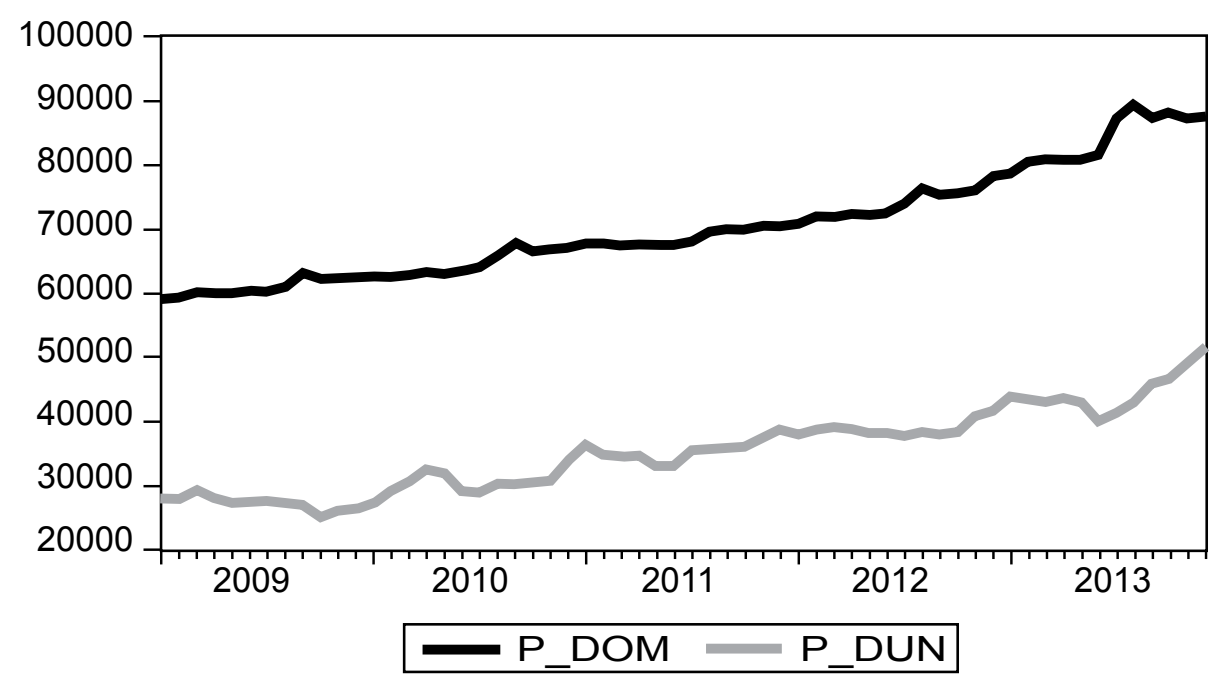

Gambar 1. Pergerakan Harga Daging Sapi Domestik dan Dunia, 2009-2013

Sumber : BPS dan Kemendag RI (2014), diolah

Berdasarkan Gambar 1. dapat diketahui bahwa harga daging sapi domestik dan harga daging sapi dunia memiliki kecenderungan atau tren yang sama yaitu harga daging sapi domestik mengalami peningkatan setiap bulannya begitu pula dengan harga daging sapi dunia yang juga mengalami peningkatan setiap bulannya. Gambar 1 juga menunjukkan bahwa harga daging sapi domestik lebih tinggi dibandingkan dengan harga daging sapi dunia. Hal ini dapat disebabkan oleh pengelolaan peternakan di luar negeri lebih efisien dibandingkan dengan di Indonesia, hal tersebut menyebabkan harga daging sapi dunia relatif lebih murah dibandingkan dengan harga daging sapi domestik.

\section{Uji Stationer}

Adapun hasil pengujian akar unit diketahui pada Tabel 1. sebagai berikut:

Tabel 1. Hasil Pengujian Akar Unit dengan Intersep tanpa Tren

\begin{tabular}{|c|c|c|c|c|c|c|}
\hline \multirow{2}{*}{ Variabel } & \multirow{2}{*}{ Differenced } & \multirow{2}{*}{$\begin{array}{l}\text { Nilai ADF } \\
\text { statistic }\end{array}$} & \multicolumn{3}{|c|}{ Intersep tanpa tren } & \multirow{2}{*}{ Kesimpulan } \\
\hline & & & $1 \%$ & $5 \%$ & $10 \%$ & \\
\hline \multirow[t]{2}{*}{ P_DOM } & $\mathrm{I}(0)$ & 0,43356 & $-3,6329$ & $-2,9484$ & $-2,6129$ & Tidak Stationer \\
\hline & $\mathrm{I}(1)$ & $-5,46771$ & $-3,6394$ & $-2,9511$ & $-2,6143$ & Stationer \\
\hline \multirow[t]{2}{*}{ P_DUN } & $\mathrm{I}(0)$ & $-1,21253$ & $-3,6329$ & $-2,9484$ & $-2,6129$ & Tidak Stationer \\
\hline & $\mathrm{I}(1)$ & $-4,70970$ & $-3,6394$ & $-2,9511$ & $-2,6143$ & Stationer \\
\hline
\end{tabular}

Sumber: BPS dan Kemendag RI (2014), diolah 
Berdasarkan Tabel 1. dapat diketahui bahwa variabel harga daging sapi domestik dan harga daging sapi dunia dilakukan uji stationer pada taraf nyata sebesar $1 \%, 5 \%$ dan $10 \%$ dengan menggunakan kriteria intersep tanpa tren. Hasil pengujian menunjukkan bahwa harga daging sapi domestik dan harga daging sapi dunia tidak stationer pada level. Hal ini ditunjukkan oleh nilai ADF yang lebih besar dari nilai kritis McKinnon. Namun, pada tingkat first difference data harga daging sapi domestik dan dunia dapat dikatakan stationer karena memiliki nilai ADF yang lebih kecil dari nilai kritis McKinnon. Adapun hasil uji stationer pada variabel harga daging sapi domestik dan dunia pada kriteria intersep dengan tren adalah sebagai berikut:

Tabel 2. Hasil Pengujian Akar Unit dengan Intersep dengan Tren

\begin{tabular}{|c|c|c|c|c|c|c|}
\hline \multirow{2}{*}{ Variabel } & \multirow{2}{*}{ Differenced } & \multirow{2}{*}{$\begin{array}{l}\text { Nilai ADF } \\
\text { statistic }\end{array}$} & \multicolumn{3}{|c|}{ Intersep dengan tren } & \multirow{2}{*}{ Kesimpulan } \\
\hline & & & $1 \%$ & $5 \%$ & $10 \%$ & \\
\hline \multirow[t]{2}{*}{ P_DOM } & $\mathrm{I}(0)$ & $-2,2660$ & $-4,2436$ & $-3,5443$ & $-3,2047$ & Tidak Stationer \\
\hline & $\mathrm{I}(1)$ & $-4,5634$ & $-4,2733$ & $-3,5577$ & $-3,2124$ & Stationer \\
\hline \multirow[t]{2}{*}{ P_DUN } & $\mathrm{I}(0)$ & $-3,9485$ & $-4,2529$ & $-3,5485$ & $-3,2071$ & $\begin{array}{l}\text { Tidak Stationer } \\
\text { pada taraf } 1 \%\end{array}$ \\
\hline & $\mathrm{I}(1)$ & $-5,0499$ & $-4,2627$ & $-3,5530$ & $-3,2096$ & Stationer \\
\hline
\end{tabular}

Sumber: BPS dan Kemendag RI (2014), diolah

Berdasarkan Tabel 2. dapat diketahui bahwa hasil pengujian stationeritas data dengan menggunakan kriteria intesep dan tren menunjukkan variabel harga daging sapi domestik tidak stationer pada tingkat level atau pada ordo nol pada taraf nyata $1 \%, 5 \%$ dan $10 \%$. Sedangkan variabel harga daging sapi dunia tidak stationer pada taraf nyata $1 \%$ saja $\mathrm{Hal}$ ini ditunjukkan dari nilai ADF masing-masing variabel yang lebih besar dari nilai kritis McKinnon. Pengujian stationeritas pada tingkat first difference menunjukkan bahwa variabel harga daging sapi domestik dan dunia adalah stationer karena memiliki nilai ADF statistic yang lebih kecil dibandingkan dengan nilai kritis McKinnon.

\section{Penentuan Lag Optimal}

Adapun panjang lag atau selang optimum yang digunakan berdasarkan kriteria Akeike Information Criteria (AIC). Panjang lag optimal dapat diketahui pada Tabel 3:

\section{Tabel 3. Kriteria Lag Optimal Harga Daging Sapi Domestik dan Dunia}

\begin{tabular}{cccc}
\hline Lag & AIC & SC & HQ \\
\hline 0 & 36.97183 & 37.06435 & 37.00199 \\
1 & 33.39753 & $33.67507^{*}$ & 33.48800 \\
2 & 33.49408 & 33.95665 & 33.64487 \\
3 & 33.25789 & 33.90550 & 33.46900 \\
4 & $33.18913^{*}$ & 34.02176 & $33.46054^{*}$ \\
5 & 33.28337 & 34.30104 & 33.61511 \\
\hline
\end{tabular}

Sumber: BPS dan Kemendag RI (2014), diolah 
Tabel 3. mengindikasikan bahwa selang optimal yang akan digunakan dalam model VAR/VECM adalah lag 4. Hal ini berdasarkan pada penentuan lag optimal dengan menggunakan kriteria Akeike Information Criteria yang menunjukkan hasil lag 4. Penentuan panjang lag otimal tersebut berguna untuk menghilangkan masalah autokorelasi dan heterosedastisitas dalam sistem VAR/VECM (Enders, 1995).

\section{Analisis Kointegrasi}

Menurut definisi Engle dan Granger (1987), kointegrasi mengacu pada sejumlah variabel yang terintegrasi pada derajat yang sama, maka dapat dilakukan uji kointegrasi. Pada penelitian mengenai integrasi pasar daging sapi domestik dan dunia, semua variabel yang digunakan baik harga daging sapi domestik maupun dunia terkointegrasi pada derajat I(1). Hal ini dikarenakan, jika variabel-variabel dalam suatu penelitian terkointegrasi pada derajat yang berbeda, maka dapat dikatakan bahwa variabel-variabel tersebut tidak dapat terkointegrasi.

Hasil pengujian kointegrasi Johansen dapat dilihat pada Tabel 4.

Tabel 4. Hasil Pengujian Kointegrasi Johansen

\begin{tabular}{rrrrrr}
\hline \multicolumn{2}{l}{ Hipotesis } & \multirow{2}{*}{ Trace Statistic } & Nilai kritis 5\% & Mx-Eigen Statistic & \multirow{2}{*}{ Nilai kritis 5\% } \\
\cline { 1 - 2 } $\mathbf{H}_{\mathbf{0}}$ & $\mathbf{H}_{\mathbf{1}}$ & & & & \\
\hline $\mathrm{r}=0$ & $\mathrm{r}=1$ & 16,01113 & 15,49471 & 15,92071 & 14,26460 \\
$\mathrm{r}=1$ & $\mathrm{r}=2$ & 0,090425 & 3,841466 & 0,090425 & 3,841466 \\
\hline
\end{tabular}

Sumber: BPS dan Kemendag RI (2014), diolah

Berdasarkan Tabel 4. dapat diketahui bahwa terdapat hubungan kointegrasi (integrasi jangka panjang) antara pasar daging sapi domestik dengan pasar daging sapi dunia. Hal ini ditunjukkan oleh nilai trace statistic maupun maximum eigenvalue menolak $\mathrm{H}_{0}$ sampai pada tingkat signifikansi $5 \%$ adalah pada rank 1, artinya terdapat satu persamaan kointegrasi (integrasi dalam jangka panjang). Dengan demikian terdapat satu persamaan yang dapat menjelaskan adanya hubungan kointegrasi pada variabel-variabel dalam model.

\section{Uji Kausalitas Granger}

Adapun hasil pengujian kausalitas Granger dapat dilihat pada Tabel 5.

Tabel 5. Hasil Pengujian Kausalitas Granger

\begin{tabular}{llcc}
\hline Null Hypothesis: & Obs & F-Statistic & Probability \\
\hline P_DUN does not Granger Cause P_DOM & 58 & 5,20873 & $0,00389^{* * *}$ \\
P_DOM does not Granger Cause P_DUN & & 1,68969 & 0,18665 \\
\hline
\end{tabular}

Sumber: BPS dan Kemendag RI (2014), diolah

Keterangan: Angka dalam [ ] adalah nilai statistik ${ }^{* * *}=$ nyata pada taraf $1 \%,{ }^{* *}=$ nyata pada taraf $5 \%$ dan * = nyata pada taraf $10 \%$. 
Tabel 5. menunjukkan bahwa berdasarkan nilai probabilitas yang dihasilkan, hanya hipotesis harga dunia yang tidak menyebabkan haga domestik yang ditolak karena memiliki probabilitas kurang dari nilai taraf nyata sebesar $5 \%$. Dengan demikian, dapat disimpulkan bahwa harga daging sapi dunia mempengaruhi terjadinya harga daging sapi domestik. Sedangkan harga daging sapi domestik tidak mempengaruhi harga daging sapi dunia. Hal ini sesuai dengan teori yang menyatakan bahwa Indonesia sebagai negara kecil (Small country) dan net importir daging sapi, maka harga daging sapi domestik dipengaruhi oleh harga daging sapi impor atau harga daging sapi dunia (Pulungan, 2014). Namun sebaliknya harga daging sapi domestik tidak dapat mempengaruhi terjadinya perubahan harga daging sapi dunia. Harga daging sapi domestik lebih mencerminkan harga konsumen di daerah sentra konsumsi (Jakarta), sehingga harga domestik yang merupakan harga ditingkat konsumen akan dipengaruhi oleh harga dunia yang merupakan cerminan harga daging sapi impor.

\section{Hasil Estimasi Vector Error Correction Model}

Adapun hasil estimasi model VECM adalah sebagai berikut:

Tabel 6. Kointegrasi Jangka Panjang antar Pasar Daging Sapi Domestik dengan Pasar Dunia

\begin{tabular}{cccc}
\hline Persamaan & \multicolumn{3}{c}{ Variabel Harga Daging Sapi } \\
\cline { 2 - 4 } Kointegrasi & P_DOM & P_DUN & C \\
\hline Kointegrasi 1 & 1.000000 & 3,545798 & $-164828,7$ \\
& & $(0,77778)$ & \\
& & {$[4,55888]^{* * *}$} & \\
\hline
\end{tabular}

Sumber: BPS dan Kemendag RI (2014), diolah

Keterangan: Angka dalam [ ] adalah nilai statistik ${ }^{* * *}=$ nyata pada taraf $1 \%,{ }^{* *}=$ nyata pada taraf $5 \%$ $\mathrm{dan}^{*}=$ nyata pada taraf $10 \%$. Nilai $\mathrm{t}$ tabel $: \mathrm{t}(\alpha=1 \%)=2.326, \mathrm{t}(\mathrm{\alpha}=5 \%)=1.960, \mathrm{t}(\mathrm{\alpha}=10 \%)=1.645$

Berdasarkan Tabel 6. dapat diketahui bahwa hanya terdapat satu persamaan yang mengalami kointegrasi pada integrasi pasar daging sapi domestik dan pasar daging sapi dunia. Sedangkan berdasarkan hubungan kausalitas yang diperoleh, hanya harga daging sapi dunia yang mempengaruhi harga daging sapi domestik (satu arah). Hal ini terjadi karena Indonesia merupakan negara kecil (small country) dan sebagai net importir daging sapi sehingga Indonesia hanya bisa dipengaruhi oleh perubahan harga daging sapi dunia tanpa dapat mempengaruhi harga daging sapi dunia. Dengan demikian, pasar dunia merupakan pasar acuan yang menentukan perubahan harga di pasar pengikut (pasar daging sapi domestik). Hal ini ditunjukkan dari persamaan jangka panjang hasil estimasi VECM yang mengindikasikan bahwa pergerakan harga daging sapi domestik dalam jangka panjang dipengaruhi oleh pergerakan harga daging sapi dunia secara signifikan pada 
taraf kepercayaan 99\%. Adapun harga daging sapi dunia berpengaruh positif terhadap harga daging sapi domestik yaitu sebesar 3,545798. Tanda positif tersebut sesuai dengan teori dimana jika terjadi peningkatan harga daging sapi dunia sebesar $1 \%$ akan direspon positif oleh pasar daging sapi domestik dengan meningkatkan harga sebesar 3,55\% dan sebaliknya jika terjadi penurunan harga daging sapi dunia sebesar $1 \%$ akan menyebabkan perubahan atau penurunan harga daging sapi domestik sebesar $3,55 \%$. Pengaruh harga daging sapi dunia terhadap harga daging sapi domestik tersebut menunjukkan perubahan yang elastis. Hal ini sesuai dengan penelitian Diakossavas (1995) yang menyatakan bahwa terdapat hubungan kointegrasi antara pasar daging sapi di AS dengan pasar daging sapi Internasional yang memiliki nilai koefisien yang positif sehingga perubahan harga di pasar internasional (Australia) akan direspon positif oleh pasar domestik. Dengan demikian dapat disimpulkan bahwa pasar daging sapi internasional atau dunia merupakan pasar acuan yang dijadikan sebagai referensi dalam menentukan perubahan harga daging sapi domestik di Indonesia. Tahapan berikutnya adalah menganalisis output VECM yang berupa vektor koreksi kesalahan (Error Correction Term). Nilai koreksi kesalahan akan menunjukkan kecepatan penyesuaian dari keseimbangan jangka pendek menuju kepada keseimbangan jangka panjang. Adapun hasil estimasi koreksi kesalahan dan output jangka pendek dari model integrasi pasar daging sapi domestik dengan dunia dapat dilihat pada Tabel 7.

\section{Tabel 7. Kointegrasi Jangka Pendek antar Pasar Daging Sapi Domestik dan Dunia}

\begin{tabular}{crr}
\hline Error Correction: & D(P_DOM) & D(P_DUN) \\
\hline CointEq1 & -0.058960 & -0.188133 \\
& $(0.04307)$ & $(0.05463)$ \\
D(P_DOM(-1)) & {$[-1.36889]$} & {$[-3.44372]^{* * *}$} \\
& -0.075107 & -0.145926 \\
& $(0.18475)$ & $(0.23433)$ \\
D(P_DOM(-2)) & {$[-0.40653]$} & {$[-0.62273]$} \\
& -0.276028 & -0.469316 \\
D(P_DUN(-1)) & $(0.18332)$ & $(0.23253)$ \\
& {$[-1.50568]$} & {$[-1.01834]$} \\
D(P_DUN(-2)) & 0.222573 & 0.518820 \\
& $(0.13224)$ & $(0.16773)$ \\
C & {$[1.68311]^{*}$} & $0.09318]^{* * *}$ \\
& -0.050496 & 0.111388 \\
& $(0.15734)$ & $(0.19957)$ \\
& {$[-0.32094]$} & $0.55815]$ \\
& 320.8223 & $(423.79664$ \\
& $(333.524)$ & {$[0.20045]$} \\
\hline
\end{tabular}

Sumber: BPS dan Kemendag RI (2014), diolah

Keterangan: Angka dalam [ ] adalah nilai statistik ${ }^{* * *}=$ sangat nyata pada taraf $1 \%,{ }^{* *}=$ nyata pada taraf $5 \%$ dan ${ }^{*}=$ nyata pada taraf $15 \%$. 
Berdasarkan Tabel 7. dapat diketahui bahwa hanya pasar daging sapi dunia yang memiliki koreksi kesalahan yang signifikan pada taraf kepercayaan 99\% sedangkan untuk pasar daging sapi domestik tidak memiliki nilai koreksi kesalahan yang berpengaruh signifikan. Nilai koreksi kesalahan yang dimiliki oleh pasar daging sapi dunia adalah sebesar $-0,188$. Artinya terdapat penyesuaian dari persamaan jangka pendek menuju jangka panjang sebesar -0,188 atau setiap bulan kesalahan dikoreksi sebesar -0,188 menuju keseimbangan jangka panjang.

Hasil kointegrasi jangka pendek yang ditunjukkan melalui tabel 7 mengindikasikan bahwa perubahan harga daging sapi domestik dalam jangka pendek dipengaruhi secara nyata pada taraf $10 \%$ oleh harga daging sapi dunia satu bulan sebelumnya. Harga daging sapi dunia pada satu bulan sebelumnya memiliki pengaruh sebesar 0,222 . Angka tersebut mengindikasikan bahwa setiap kenaikan harga domestik pada satu bulan sebelumnya sebesar $1 \%$ akan meningkatkan harga domestik pada periode sekarang sebesar $0,222 \%$. Pengaruh positif tersebut sesuai dengan teori yang menyatakan bahwa negara Indonesia merupakan negara net importir daging sapi sehingga harga daging sapi domestik sangat tergantung pada perubahan harga daging sapi dunia. Pengaruh positif tersebut mengindikasikan jika terjadi peningkatan harga daging sapi dunia maka akan direspon oleh pasar daging sapi domestik dengan meningkatkan harga daging sapi dan sebaliknya. Hal ini menunjukkan bahwa pembentukan harga daging sapi domestik ditentukan oleh perubahan harga daging sapi dunia sebagai pasar acuan. Hubungan positif tersebut sejalan dengan Gambar 1. yang menunjukkan bahwa pasar daging sapi domestik dan dunia memiliki tren peningkatan harga yang sama sehingga harga daging sapi dunia memiliki pengaruh yang positif terhadap perubahan harga daging sapi domestik.

Sedangkan harga daging sapi dunia dalam jangka pendek dipengaruhi harga daging sapi dunia sendiri pada satu bulan sebelumnya. Harga daging sapi dunia pada satu bulan sebelumnya memberikan pengaruh yang nyata pada taraf kepercayaan 99\% dimana besarnya pengaruh sebesar 0,111. Angka tersebut mengindikasikan bahwa pembentukan harga daging sapi dunia mengacu terhadap perubahan harga daging sapi dunia pada periode sebelumnya yaitu jika terjadi kenaikan harga dunia pada satu bulan sebelunya sebesar $1 \%$ maka akan menyebabkan harga daging sapi dunia pada periode sekarang akan meningkat sebesar $0,111 \%$. Hal ini juga menunjukkan bahwa tren harga daging sapi dunia akan terus mengalami peningkatan setiap periodenya jika dilihat dalam jangka pendek. Adanya integrasi pasar daging sapi domestik dan dunia yang bersifat satu arah dalam jangka pendek maupun jangka panjang menunjukkan bahwa pasar daging sapi domestik belum efisien.

\section{KESIMPULAN DAN REKOMENDASI KEBIJAKAN}

Harga daging sapi domestik dipengaruhi oleh harga daging sapi dunia/ internasional secara positif (jika 
harga daging sapi dunia meningkat maka harga daging sapi domestik juga akan mengalami peningkatan dan sebaliknya). Hubungan tersebut menunjukkan adanya integrasi pasar daging sapi domestik dengan pasar daging sapi dunia/ internasional dalam jangka panjang (kointegrasi) dan jangka pendek namun masih terdapat ketidakseimbangan sehingga dibutuhkan penyesuaian untuk mencapai kesimbangan jangka panjangnya. Berdasarkan hasil uji kausalitas Granger diperoleh hasil bahwa hanya harga daging sapi dunia yang mempengaruhi harga daging sapi domestik sedangkan harga daging sapi domestik tidak dapat mempengaruhi harga daging sapi dunia. Hal ini disebabkan negara Indonesia merupakan negara kecil dan net importir daging sapi, sehingga perubahan yang terjadi di pasar internasional akan mempengaruhi harga daging sapi domestik, namun sebaliknya perubahan harga daging sapi domestik tidak dapat mempengaruhi harga daging sapi dunia. Hubungan integrasi yang bersifat satu arah menunjukkan bahwa pemasaran daging sapi domestik masih belum efisien.

Berdasarkan hasil penelitian dapat diketahui bahwa dalam jangka panjang harga daging sapi domestik dipengaruhi oleh harga daging sapi dunia (impor), yang menunjukkan bahwa Indonesia adalah negara importir daging sapi, sehingga stabilitas harga daging sapi Indonesia tergantung pada harga daging sapi dunia. Oleh karena itu, pemerintah melalui Kementerian Perdagangan perlu menerapkan kebijakan stabilitas harga daging sapi agar konsumen dapat menjangkau harga daging sapi yang terus meningkat serta produsen juga tidak dirugikan.

\section{UCAPAN TERIMA KASIH}

Penulis mengucapkan rasa terima kasih kepada Dr. Ir. Anna Fariyanti, M.Si. dan Prof. Dr. Ir. Sri Hartoyo, M.S. atas masukannya selama penulisan penelitian ini. Penulis juga mengucapkan terima kasih kepada rekan kerja Fanani, Nuni, Rini, Gita, Joko, Mas Ibram, Stevana, Kak Peby dan Mas Doddy, atas dukungannya. Rekan-rekan sesama pejuang di Program Studi IImu Ekonomi Pertanian Angkatan 2013, dukungan morilnya selama ini tidak pula penulis lupakan.

\section{DAFTAR PUSTAKA}

Ajija S, Setianto D, Primanti M. (2011). Cara Cerdas Menguasai Eviews. Jakarta: Salemba Empat.

Asmarantaka, R.W. (2009). Pemasaran Produk-produk Pertanian. Bunga Rampai Agribisnis: Seri Pemasaran. Bogor: IPB Press.

Asmarantaka, R.W. (2012). Pemasaran Agribisnis (Agrimarketing). Bogor: Departemen Agribisnis FEM IPB.

Badan Pusat Statistik. (2014). Statistik Harga Konsumen Pedesaan di Indonesia. Jakarta: Badan Pusat Statistik.

Diakosavvas, D. (1995). How Integrated are World Beef markets? The Case of Australian and U.S. Beef Markets. Agricultural Economics. Vol. 12 (2), pp. 37-53.

Direktorat Jenderal Peternakan dan Kesehatan Hewan. (2013). Statistik Peternakan dan Kesehatan Hewan (Livestock and Animal Health 
Statistics) 2012. Jakarta: Direktorat Jenderal Peternakan dan Kesehatan Hewan Kementerian Pertanian Republik Indonesia.

Enders, Walter. (1995). Applied Econometric Time Series. New York: John Wiley \& Sons.

Engle, Robert F. \& Clive W.J. Granger (1987), "Co-integration and error correction: representation, estimation, and testing", Econometrica. Vol. 55, pp. 251-276.

Firdaus, M. (2011). Aplikasi Ekonometrika untuk Data Panel dan Time Series. Bogor: IPB Press.

Food and Agriculture Organization (FAO). (2014). Trade Yearbook. Rome: Food and Agriculture Organization.

Fossati, Sebastian; Lorenzo \& Rodriguez. (2012). Regional and International Market Integration Of A Small Open Economy. Journal of Applied Economics. Vol. 10 (1), pp. 77-98.

Goodwin, B.K., \& T.C. Schroeder. (1991). Cointegration Test and Spatial Price Linkage in Regional Cattle Markes. American Journal of Agricultural Economics. Vol. 73 (2), pp. 452-464.

Granger, C.W.J. (1969). "Investigating Causal Relationships by Econometric Models and Cross Spectral Methods." Econometrica, Vol. 37 (1), pp. 424-438.

Gujarati, Damodar. (2004). Basics Econometrics, Fourth Edition. United State: The McGraw Hill Companies.

Harmini, Asmarantaka, R.W., \& Atmakusuma, Y. (2011). Model Dinamis Sistem Ketersediaan Daging Sapi Nasional. Jurnal Ekonomi Pembangunan. Vol. 12 (1), pp.130-148.

Ilham, N. (2006). Analisis Ekonomi dan Strategi Pencapaian Swasembada
Daging 2010. Makalah dipresentasikan pada pertemuan Koordinasi Teknis Direktorat Budidaya Ternak Ruminansia Ditjen Peternakan, Bogor 27 April 2006.

Ilham, N. (2009). Kelangkaan Produksi Daging: Indikasi dan Implikasi Kebijakannya. Analisis Kebijakan Pertanian. Vol. 7 (1), pp. 43-63.

Istiqomah, N.S. (2014). KerjasamaAustraliaIndonesia dalam Bidang Ekspor Impor Daging Sapi. Skripsi. Fakultas IImu Sosial dan IImu Politik, Universitas Hasanuddin.

Kementerian Perdagangan RI. (2014). Statistik Harga Internasional 20082013. Diunduh tanggal 05 September 2014 dari http://www.kemendag. go.id/id/economic-profile/prices/ international-price-table?year=2013.

Kusriatmi. (2014). Dampak Kebijakan Swasembada Daging Sapi Terhadap Kinerja Ekonomi Subsektor Peternakan di Indonesia. Disertasi. Bogor : Pascasarjana Institut Pertanian Bogor. Maraya, G.Q. (2013). Faktor-Faktor yang Memengaruhi Impor Daging Sapi di Indonesia. Skripsi. Fakultas Ekonomi dan Manajemen, Institut Pertanian Bogor.

Negassa, A., R. Meyers \& E. G. Maldhin (2003), "Analyzing the Grain Market Efficiency in Developing Countries: Review of Existing Methods and Extensions to the Parity Bound Model," Market Trade and Institutions Division, Discussion Paper 63.

Pulungan, R.E. (2014). Dampak Kebijakan Indonesia Membatasi Kuota Impor Daging Sapi dari Australia. Jom FISIP. Vol. 1 (2), pp. 1-10. 
Ravallion. (1986). Testing Market Integration. American Journal of Agricultural Economics. Vol. 68 (1), pp. 102-109.

Rosadi, Dedi. (2012).Ekonometrika dan Analisis Runtun Waktu Terapan dengan Eviews. Yogyakarta: Penerbit Andi Yogyakarta.

Sutawi. (2007). Kapita Selekta Peternakan. Malang: UMM Press.

Tomek, William. \& Kenneth Leon Robinson. (1990). Agricultural Product Prices. London: Cornell University Press.
Tseuoa T. (2011). Impact of ASEAN Australia and New Zealand Free Trade Agreement on Beef Industry in Indonesia. Thesis. Bogor: Graduate School of Bogor Agricultural University. Widarjono A. (2012). Ekonometrika Pengantar dan Aplikasinya. Yogyakarta: Ekonisia.

Yustiningsih, F. (2012). Analisa Integrasi Pasar dan Transmisi Harga Beras Petani-Konsumen di Indonesia. Tesis. Jakarta: Fakultas Ekonomi Universitas Indonesia 